EGU2020-10027

https://doi.org/10.5194/egusphere-egu2020-10027

EGU General Assembly 2020

(c) Author(s) 2021. This work is distributed under

the Creative Commons Attribution 4.0 License.

\title{
Erosion and sediment enrichment ratio in volcanic soils
}

\author{
Ludmila La Manna ${ }^{1,2}$, César Mario Rostagno ${ }^{2,3}$, Manuela Tarabini ${ }^{1,2}$, Federico Gomez ${ }^{1,2,4}$, and Ana \\ Navas $^{5}$ \\ ${ }^{1}$ Centro de Estudios Ambientales Integrados (CEAI), Facultad de Ingeniería, Universidad Nacional de la Patagonia San Juan \\ Bosco, Sede Esquel, Chubut, Argentina \\ ${ }^{2}$ Consejo Nacional de Investigaciones Científicas y Técnicas (CONICET), Argentina *Corresponding author: \\ ludmilalm@yahoo.com \\ ${ }^{3}$ Unidad de Investigación Ecología Terrestre, CENPAT-CONICET, Puerto Madryn, Chubut, Argentina \\ ${ }^{4}$ Instituto Nacional de Tecnología Agropecuaria (INTA), Estación Experimental Agroforestal Esquel, Chubut, Argentina \\ ${ }^{5}$ Estación Experimental de Aula Dei, Spanish National Research Council (EEAD-CSIC), Avda. Montañana 1005, Zaragoza, \\ 50059, Spain.
}

Patagonian Andean region is widespread affected by soil degradation and erosion processes. The subhumid sector, which corresponds to the transition (ecotone) between the Andean forests and the Patagonian steppe, has suffered the highest human pressure and overgrazing, accelerating the soil erosion processes.

Near Esquel town (Subhumid sector of Chubut province, Argentina), where soils are mainly developed from volcanic ashes, erosion studies based on fallout radionuclides (Caesium-137) and simulated rainfalls were performed. Studies based on Caesium-137 showed that soil losses in the last 50 years were higher than $30 \mathrm{~m}^{3} \mathrm{ha}^{-1}$ year $^{-1}$ under different land uses.

Rainfall simulation experiments, carried out under the same conditions (Rain fall intensity: 100 $\mathrm{mm} \mathrm{h}^{-1}$ for 30 minutes; Drop diameter: $2.5 \mathrm{~mm}$; Drop velocity: $5.3 \mathrm{~m} \mathrm{~s}^{-1}$ ) showed that erosion rates are highly affected by land use. Potential erosion rates in degraded rangelands varied between 143 and $750 \mathrm{~g} \mathrm{~m}^{-2}$, depending on soil characteristics (such as texture and presence of noncrystalline materials), soil cover and slope. In mature exotic conifer afforestations, with soil completely covered by litter, soil erosion was negligible, varying between 0 and $10 \mathrm{~g} \mathrm{~m}^{-2}$. Erosion rates increased both in young afforestations with open canopies $\left(8 \mathrm{a} 44 \mathrm{~g} \mathrm{~m}^{-2}\right)$, and in mature afforestations where fresh litter and duff layers were removed (35 a $200 \mathrm{~g} \mathrm{~m}^{-2}$ ).

In the different studied systems, soil losses involved not the detachment of individual particles, but of soil micro aggregates rich in organic matter. Sediments enrichment ratio was always higher than 1, varying between 1.2 and 1.8. These results show that the sediments were enriched with organic matter, as compared to the contributing soils, indicating its selective removal. The erosion studies performed evidence the high erodibility of volcanic soils when their cover is lost, and the close link between erosion and carbon losses in these systems. 